In spite of the present difficulty of explaining the reason for the clustering in young children with leukaemia, it would seem important to pursue studies in this field. This should be done prospectively in order to make possible an immediate search for aetiological factors as soon as clusters are suspected. The organization of large-scale prospective surveys is beset by many difficulties, but these diminish when it is possible to confine the investigation to well-defined groups. In view of the findings here discussed, it is now suggested that future surveys of leukaemia clusters might with advantage be confined to the group most likely to show the effect-children under the age of 6 years.

This investigation was supported by the Canterbury and Westland Division of the Cancer Society of New Zealand. The field work was conducted by Mrs. Barbara Stroud, for whose skill and enthusiasm we are most grateful.

\section{REFERENCES}

Barton, D. E., David, F. N., and Merrington, M. (1965). Ann. hum. Genet., 29, 97.

Dameshek, W., and Gunz, F. (1964). Leukemia, 2nd ed. New York.
Dowsett, E. G. (1966). Brit. 7. Cancer, 20, 16.

Ederer, F., Myers, M. H., Eisenberg, H., and Campbell, P. C. (1965). f. nat. Cancer Inst. 35, 625.

Ederer, F., Myers, M. H., and Mantel, N. (1964). Biometrics, 20, 626 Goldenberg, G. J., and Zarowski, V. S. (1967). Cancer (Philad.), 20

2.200.
Gunz, F. W. (1966). N.Z. med. 7., 65, 857.

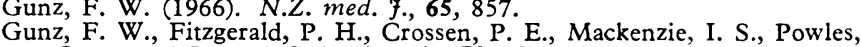
C. P., and Jensen, G. R. (1966). Blood, 27, 482.

Heath, C.' W., jun., and Hasterlik, R. J. (1963). Amer. f. Med., 34, 796.

Heath, C. W., jun., Manning, M. D., and Zelkowitz, L. (1964). Lancet, 2, 136.

Kellett, C. E. (1937). Arch. Dis. Childh., 12, 239.

Knox, G. (1963). Brit. F. prev. soc. Med., 17, $12 \mathrm{i}$

Knox, G. (1964). Brit. F. prev. soc. Med., 18, 17.

Knox, G. (1964). Brit. F. prev. soc. Med., 18,

Lee, J. A. H. (1962). Brit. med. 7., 1, 1737.

e, J. A. H., and Gardner, M. J. (1965). In Current Research in Leukaemia, edited by F. G. J. Hayhoe, p. 266 . London.

Lundin, F. E., jun., Fraumeni, J. F., jun., Lloyd, J. W., and Smith, E. M. (1966). Ұ. nat. Cancer Inst., 37, 123.

MacMahon, B. (1968) Cancer (Philad.), 21, 558.

Mainwaring, D. (1966). Lancet, 2, 393 .

Mustacchi, P. (1965). Cancer (Rhilad.), 18, 362.

Pinkel, D., and Nefzger, D. (1959). Cancer (Philad.), 12, 351.

Stark, C. R., and Mantel, N. (1967). Cancer Res., 27, 1749.

Stewart. A., and Hewitt, D. (1965). In Current Topics in Radiation Research, edited by M. Ebert and A. Howard, p. 221. Amsterdam.

Till, M. M., Hardisty, R. M., Pike, M. C., and Doll, R. (1967). Brit. med. F., 3, 755 .

\title{
Diarrhoea in Kwashiorkor
}

\author{
BRIAN WHARTON,* M.D., M.R.C.P., M.R.C.P.ED., D.C.H.; GLAN HOWELLS, †; IAN PHILLIPS, $\ddagger$ M.A., M.D.
}

\begin{abstract}
Cummary: Diarrhoea was a common problem in the kwashiorkor seen in Kampala, contributing to the mortality and delay in recovery. Enteric infection was found in only a few children $(8 \%)$, but when present it caused particularly severe diarrhoea and was frequently complicated by septicaemia.

Sugar intolerance often occurred to lactose and other sugars, both monosaccharide and disaccharide. The children were most commonly intolerant of lactose, a:d some of these may have had a hereditary lactase deficiency.

Antibiotics are rarely indicated for the treatment of diarrhoea in kwashiorkor in Kampala. If reducing substances are found in the stool of a child on a milk diet, a diet based on sucrose is substituted, and if intolerance persists a fructose diet is given. A few children are intolerant of all sugars, including fructose, and for these the prognosis is grave.
\end{abstract}

\section{Introduction}

In 1908 a curious disease known as "culebrilla" was described in Yucatan, Mexico (Correa, 1908). In this disease, which later became known as kwashiorkor, intractable diarrhoea was the chief sign, and it has remained a prominent feature of all subsequent descriptions. In early work from Uganda, Dean (1952) implicated carbohydrate intolerance, particularly of lactose, as a major factor in the aetiology of the diarrhoea, and

* Paediatrician, M.R.C. Infantile Malnutrition Research Unit, Kampala, Uganda. Present address: Department of Child Health, University of Bristol.

† Technical Officer, M.R.C. Infantile Malnutrition Research Unit, Kampala, Uganda. Present address : M.R.C. Radiobiology Research Unit, Harwell, Berkshire.

¥Lecturer, Department of Microbiology, Makerere Medical School, Kampala, Uganda. lactose intolerance in children with kwashiorkor has been clearly established in Cape Town (Bowie, Brinkman, and Hansen, 1965 ; Bowie, Barbezat, and Hansen, 1967). In other South African centres infection has been thought to be the cause (Kahn, 1959 ; Scragg and Rubidge, 1960), and in Mexico enteritic infection certainly contributes to the high mortality rate (Galván and Calderon, 1965).

The clinical problem in Uganda has sometimes been diarrhoea that appears after a day or so of treatment and becomes increasingly severe. This diarrhoea rarely responded to antibiotics. A lactose-free diet containing glucose and sucrose was not always successful, and one child had reducing substances in his stool when receiving oral dextrose only. The differing views on aetiology and the difficulties of management suggested that a combined clinical, biochemical, and bacteriological approach to the problem might be of value, and this was made in 71 children admitted to the unit for the treatment of malnutrition. Preliminary results were presented at the Cambridge Symposium in 1967 (Wharton, 1968).

\section{Methods}

\section{Bacteriology}

The stools of all the children were examined for the presence of salmonellae, shigellae, and pathogenic Escherichia coli, on admission and thereafter as indicated clinically by persistent diarrhoea or a suspected septicaemia. The samples were cultured on MacConkey agar, desoxycholate-citrate agar, and in selenite broth. Standard bacteriological examinations were also made on specimens from other infected sites. All children with kwashiorkor have diarrhoea. It was regarded as "mild" if the child passed fewer than three stools per day, "moderate" if three to five loose stools were obtained, and "severe" if more than five loose or fluid stools were passed. 


\section{Sugar Tolerance}

The first 50 children were investigated for sugar intolerance only if they had diarrhoea and a reducing substance was found in the stool (Clinitest) and/or the stool $\mathrm{pH}$ (Universal indicator paper) was below 6. If either of these indications was positive, test doses of lactose, sucrose, glucose, galactose, and fructose ( $2 \mathrm{~g} . / \mathrm{kg}$. body weight) were given separately to the child as his clinical condition allowed. If the child was very ill it was not always possible to investigate all the sugars.

All of the last 21 patients were tested, so far as possible, whether they had diarrhoea or not. A monosaccharide load (glucose $1 \mathrm{~g} . / \mathrm{kg}$., galactose $1 \mathrm{~g}$. $/ \mathrm{kg}$.) as described by Anderson, Kerry, and Townley (1965) was given on the day of admission and on the next day a disaccharide load (lactose 10 g., sucrose $10 \mathrm{~g}$. for children less than $10 \mathrm{~kg}$.) similar to that described by Arthur, Clayton, Cottom, Seakins, and Platt (1966) was given. Lastly, if the monosaccharide load had revealed intolerance a final load of fructose $(2 \mathrm{~g} . / \mathrm{kg}$.) was given.

The test sugars were given with carmine and the subsequent marked stools collected until an unmarked one was passed. Urine was collected for at least six hours immediately following the start of the test.

\section{Chemical Methods}

The freshly passed marked stool and the urine were immediately stored at $-20^{\circ} \mathrm{C}$. to inhibit bacterial action. The faeces were later thawed and the $p \mathrm{H}$ was determined by means of universal indicator paper. They were then homogenized and the volume was measured. If the stool was only semi-fluid it was sometimes necessary to add distilled water to obtain a satisfactory homogenate. Approximately $40 \mathrm{ml}$. of the homogenate was centrifuged and the supernatant retained for lactic acid determination (Barker and Summerson, 1941) and sugar chromatography. Then $6 \mathrm{ml}$. of the supernatant was shaken with about $3 \mathrm{ml}$. of Biodeminrolit resin (Permutit, London) in the bicarbonate form and the faeces-resin mixture was centrifuged. A suitable aliquot $(5-50 \mu \mathrm{l}$.) of the supernatant solution was chromatographed in duplicate on each of two sheets of Whatman No. 3 paper, the descending technique being used. An aldose standard (2.4 mg. lactose, $0.8 \mathrm{mg}$. galactose, and $1.6 \mathrm{mg}$. glucose per $\mathrm{ml}$.) was spotted in 10, 20, and $25-\mathrm{ml}$. amounts on one sheet, and on the other sheet similar amounts of a ketose standard (1.6 mg. sucrose and $0.8 \mathrm{mg}$. fructose $/ \mathrm{ml}$.) were spotted. The chromatograms were allowed to run overnight in an ethyl acetate: pyridine : water solvent $60: 25: 20$ and then dried in a current of air until free of solvent. The aldose sugars were located with aniline phosphate reagent and the ketose sugars with naphthoresorcinol-trichloracetic acid reagent (Arthur et al., 1966). The quantities were assessed by visual comparison with the standards. The reducing substances in the stool, as determined with a Clinitest tablet, agreed with the amounts determined by chromatography $(y=$ Clinitest, $\mathrm{x}=$ chromatographic $: \mathrm{y}=0.80 \mathrm{x}+200 \mathrm{mg}$.).

The following three case reports illustrate the clinical problems involved.

\section{Case 1. Mixed Sugar Intolerance. Enteric Infection}

A 25-month-old Baganda girl (Bantu) who had been admitted to the Save the Children Fund Nutrition rehabilitation centre two weeks previously with moderate kwashiorkor and measles was transferred to this unit because of severe diarrhoea. Overt signs of kwashiorkor were no longer present but she was moderately dehydrated, had a temperature of $100^{\circ} \mathrm{F}$. $\left(37.8^{\circ} \mathrm{C}\right.$.), and there was evidence of growth retardation (weight and height below third percentile, weight $60 \%$ of that to be expected for her age) and residual protein deficiency (plasma proteins $5.6 \mathrm{~g} / 100 \mathrm{ml}$., aminoacid ratio 4.8). Her haemoglobin was $12 \mathrm{~g} . / 100 \mathrm{ml}$.
Blood for culture and other specimens for bacteriological examination were collected and the routine diet containing dried skimmed milk, sucrose, and cottonseed oil, together with extra water and potassium chloride, was given. Reducing substances were found in the stool, together with a low $p \mathrm{H}$, and thereafter the child was given a diet containing casein, fructose, and cottonseed oil with extra potassium and magnesium. The diarrhoea was only partially controlled, but there was no further loss of weight.

She remained very ill, however ; her temperature rose to $102^{\circ} \mathrm{F}$. $\left(38.9^{\circ} \mathrm{C}\right.$.) and her haemoglobin fell by $1.3 \mathrm{~g} . / 100 \mathrm{ml}$. Seventy-two hours after admission further blood was taken for culture and tetracycline was prescribed. Her temperature thereupon gradually fell to normal, the diarrhoea diminished, and after four days on tetracycline her appetite improved and her weight began to rise. Salmonella garoli was isolated from both blood cultures and the throat swab.

Table I shows the results of the sugar load investigations soon after her admission and the tests performed three weeks later. By this time she was growing well (hydroxyproline index $=2.5$ ) and there was no evidence of protein deficiency (plasma protein $=6.4 \mathrm{~g} . / 100$ ml., amino-acid ratio 1.4). The haemoglobin level, which had fallen to $9.4 \mathrm{~g} . / 100 \mathrm{ml}$., rose again to $11.2 \mathrm{~g} . / 100 \mathrm{ml}$. Though initially she was intolerant to all sugars except fructose, only lactose intolerance remained at the time of discharge.

TABLE I.-Effect of Sugar Loads (2 g./kg.) on Child With Enteric Infection (Case 1)

\begin{tabular}{|c|c|c|c|c|c|c|c|c|c|c|}
\hline & \multicolumn{5}{|c|}{ Admission } & \multicolumn{5}{|c|}{ Discharge } \\
\hline & 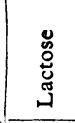 & $\begin{array}{l}\text { o } \\
\text { ơ } \\
\text { ڤ્ }\end{array}$ & 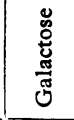 & $\begin{array}{l}\text { O } \\
\stackrel{\Xi}{3} \\
0\end{array}$ & 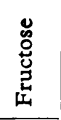 & 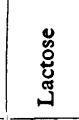 & 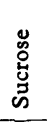 & 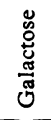 & 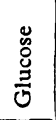 & 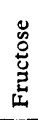 \\
\hline $\begin{array}{l}\text { Faeces (mg.) } \\
\text { Urine (mg.) }\end{array}$ & $\begin{array}{r}5,000 \\
100\end{array}$ & $\begin{array}{r}400 \\
10\end{array}$ & 1,000 & 1,000 & $\begin{array}{r}100 \\
20\end{array}$ & 4,000 & 二 & 100 & 二 & - \\
\hline
\end{tabular}

\section{Case 2. Lactose Intolerance}

An 18-month-old boy with moderate kwashiorkor (plasma proteins $4.0 \mathrm{~g} . / 100 \mathrm{ml}$.) had begun a diuresis on the second day of admission and, apart from three episodes of hypothermia $\left(96-96.4^{\circ} \mathrm{F} ; 35.6-\right.$ $35.8^{\circ} \mathrm{C}$.), appeared to be making uneventful progress. The stools, however, were loose on admission and became increasingly so over the next few days. Lactose in the stool was demonstrated on the third day, but sucrose and a glucose/galactose load were handled normally and these sugars were not excreted. Culture of the stool revealed no bacterial pathogens. A lactose-free diet based on sucrose and Casilan was substituted and the diarrhoea quickly abated. Two weeks later, when he was well (plasma protein $6.4 \mathrm{~g} . / 100 \mathrm{ml}$.), a lactose load did not precipitate diarrhoea and only small amounts of lactose $(100 \mathrm{mg}$.) were found in the stool. The diarrhoea was never severe enough to threaten life in this child, but recovery might have been delayed if the diarrhoea had persisted.

\section{Case 3. Mixed Sugar Intolerance. Pneumonia}

A boy with severe kwashiorkor and wasting (triceps skinfold thickness, $4 \mathrm{~mm}$.) was admitted with a pyrexia $\left(102^{\circ} \mathrm{F} . ; 38.9^{\circ} \mathrm{C}\right.$.) and raised respiratory rate (60 per minute). There were no localizing signs in the chest, but an $x$-ray film showed bronchopneumonic changes in the right middle and lower lobes. A throat swab taken before antibiotic therapy grew Pseudomonas aeruginosa; blood culture and urine culture were negative. Tetracycline was started on the second day.

A reducing substance in the stool was found after the child had received only two feeds; the stool $p \mathrm{H}$ was 6 . Sugar loads showed that he was intolerant of lactose and sucrose but not of monosaccharides. From day 2 he received a fructose diet and over the next week the diarrhoea improved considerably (fewer than three stools per day).

With tetracycline therapy the pyrexia and the tachypnoea fell, with considerable clinical improvement, but on the 10th day fever reappeared and the respiratory rate began to rise. An $x$-ray film at this time showed a considerable spread of the pneumonic process, which now involved both lungs. The Mantoux $1 / 100$ performed 
on admission had been negative, his mother's chest $x$-ray picture was normal, there was no history of tuberculosis contact, and repeated cultures from gastric washings and laryngeal swabs did not reveal Mycobacterium tuberculosis. Cloxacillin was tried, but with little improvement, though a throat swab subsequently revealed Ps. aeruginosa, Klebsiella aerogenes, and Staphylococcus aureus resistant to penicillin and tetracycline. Chloramphenicol was added to the regimen during the three days preceding death on the 27th day. Though sugar did not reappear in the stools the diarrhoea became worse, and for the last five days of his life he was passing about 12 stools per day.

\section{Group Results}

Table II shows the number of children with loose motions and the prevalence of enteric infection and sugar intolerance. Diarrhoea was a considerable problem in 14 of the $71(20 \%)$ children investigated and was troublesome in a further 30 (42\%).

TABLE II.-Stool Examination in 71 Children with Kwashiorkor

\begin{tabular}{|c|c|c|c|c|c|}
\hline \multirow{3}{*}{$\begin{array}{c}\text { Severity } \\
\text { of } \\
\text { Diarrhoea }\end{array}$} & \multirow{3}{*}{$\begin{array}{l}\text { No. of } \\
\text { Children }\end{array}$} & \multirow{2}{*}{\multicolumn{2}{|c|}{$\begin{array}{c}\text { Sugar Present in Stool } \\
\text { Stool Pathogen }\end{array}$}} & \multirow{3}{*}{$\begin{array}{c}\text { No } \\
\text { Stool } \\
\begin{array}{c}\text { Abnormality } \\
\text { Noted }\end{array}\end{array}$} & \multirow{3}{*}{ Deaths } \\
\hline & & & & & \\
\hline & & Present & Absent & & \\
\hline $\begin{array}{l}\text { Severe . } \\
\text { Moderate } \\
\text { Mild } \quad \text {. }\end{array}$ & $\begin{array}{l}14 \\
30 \\
27\end{array}$ & $\begin{array}{l}5 \\
1 \\
-*\end{array}$ & $\begin{array}{l}5 \\
8 \\
2\end{array}$ & $\begin{array}{r}4 \\
21 \\
25\end{array}$ & $\begin{array}{l}4(28 \%) \\
4(13 \%) \\
2(7 \%)\end{array}$ \\
\hline Total & 71 & 6 & 15 & 50 & $10(14 \%)$ \\
\hline
\end{tabular}

* Three children had pathogens present in their stool, but the diarrhoea was mild and no sugars were demonstrated in the stool. They have been regarded as carriers.

A specific enteric infection was found only in six children $(8 \%)$ but all except one of these had severe diarrhoea (see Table II). Five had a complicating septicaemia and they were all very ill and had intestinal sugar intolerance. Salm. stanley was found in one child and Salm. garoli in the other five.

Three other children had pathogens in the stool-Shigella sonnei, Salm. typhimurium, and Salm. garoli. Diarrhoea was very mild and they have been regarded as carriers.

Apart from the six children with salmonella enteritis a further 15 had sugar in their stools (Table II). The diarrhoea was moderate in eight and severe in five of them.

The Chart shows the results of the sugar loads shortly after admission in the 21 children with intolerance, and in the 11 survivors two to three weeks later. Lactose intolerance predominated and persisted in three children for some weeks. Intolerance to monosaccharides and other disaccharides was less common and persisted in only one child.

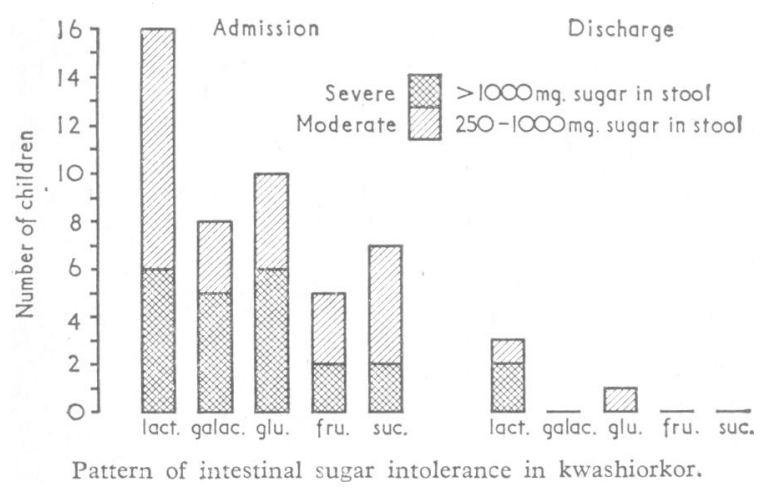

Of the 21 children with sugar intolerance, five were considered too ill to receive all the loads. In the remaining 16, however, it was possible to follow the full sugar load protocol. Table III shows the pattern of sugar intolerance which was found in these children. The children with enteric infection showed a mixed intolerance of at least three sugars, with residual intolerance of lactose in two. Three of them were intolerant of all five sugars, including fructose. The non- infected children showed a different pattern, however, in that half were intolerant of lactose alone and fructose intolerance (intestinal) occurred in only one child.

TABLE III.-Pattern of Sugar Intolerance in 16 Intolerant Children Who Completed the Sugar Load Protocol

\begin{tabular}{|c|c|c|c|c|c|c|}
\hline \multirow[b]{2}{*}{$\begin{array}{c}\text { Enteric } \\
\text { Pathogens } \\
\text { in Stool }\end{array}$} & \multirow[b]{2}{*}{ No. } & \multicolumn{3}{|c|}{$\begin{array}{c}\text { Pattern of Intestinal Intolerance } \\
\text { on Admission }\end{array}$} & \multicolumn{2}{|c|}{ Survivors } \\
\hline & & $\begin{array}{c}\text { Intolerant } \\
\text { of } \\
\text { Lactose } \\
\text { Only }\end{array}$ & $\begin{array}{c}\text { Mixed } \\
\text { Intolerance } \\
\text { of Various } \\
\text { Sugars but } \\
\text { Excluding } \\
\text { Fructose }\end{array}$ & $\begin{array}{c}\text { Intolerant } \\
\text { of All Sugars, } \\
\text { Including } \\
\text { Fructose }\end{array}$ & No. & $\begin{array}{c}\text { Residual } \\
\text { Intolerance } \\
\text { Present }\end{array}$ \\
\hline $\begin{array}{l}\text { Absent } \\
\text { Present }\end{array}$ & $\begin{array}{r}10 \\
6\end{array}$ & $\underline{5}$ & $\mathbf{4}^{*}$ & $\begin{array}{l}1 \\
3\end{array}$ & $\begin{array}{l}7 \\
4\end{array}$ & $\begin{array}{l}1 \text { (lactose) } \\
2 \text { (lactose) }\end{array}$ \\
\hline
\end{tabular}

* One child was intolerant of lactose and sucrose, the other three were intoleran of lactose, and two or three of sucrose/glucose/galactose.

\section{Discussion}

Sugar intolerance was a relatively common cause of diarrhoea in children with kwashiorkor admitted to hospital in Kampala.

A few of the children had a specific enteritis and all of these showed sugar intolerance as well. It is difficult to interpret this association, since the appearance of sugar in the stools of these severely ill children could conceivably have been due to intestinal hurry alone rather than to an enzyme deficiency of the gut mucosa. It seems probable, however, that bacterial infection was the final insult to the already malnourished mucosa in these children, resulting in severe damage and an intolerance of most of the sugars.

Apart from the children with infection, however, sugar intolerance was quite a common cause of diarrhoea and sometimes very severe diarrhoea. Lactose intolerance is now well documented in kwashiorkor but clinical intolerance of sucrose has not been demonstrated before. It is, however, in keeping with the deficiency of sucrase in jejunal biopsies of children with kwashiorkor which has been found in Kampala (Stanfield, Hutt, and Tunnicliffe, 1965), Cape Town (Bowie et al., 1967), and Jamaica (James, 1968). Clinical intolerance of monosaccharides in kwashiorkor also appears to be an original observation. Defects of glucose absorption in kwashiorkor have, however, been demonstrated by blood glucose studies in Guatemala (Viteri, Flores, and Behar, 1967) and an intubation technique in Jamaica (James, 1968).

Much of the sugar intolerance in Kampala may be secondary to a mucosal defect in kwashiorkor. In some of the children, however, such as those with a lone lactose intolerance or with a residual lactose intolerance, it is probable that a hereditary lactase deficiency was involved (Cook and Kajubi, 1966).

Antibiotics seem of limited value, since specific infections are rare. There was no evidence that antibiotics had any effect on diarrhoea unless a specific gut pathogen had been found, but a full controlled trial would be necessary to test that point. Whenever a reducing substance (Clinitest) appears in the stool the sugar content of the diet should be reconsidered. The sugar load techniques revealed a number of instances of intolerance which were not clinically apparent, and no doubt a number of these would have progressed satisfactorily without any dietary manipulation. It seems probable, however, that suitable dietary manœuvres did speed recovery in many of them, and in the occasional child removal of the offending sugar(s) proved life-saving.

The pattern of sugar intolerance, particularly when there is no enteric infection, suggests that a lactose-free diet based on Casilan, sucrose, and cottonseed oil would reduce sugar intolerance by about a half, and that if the child is still intolerant fructose should be substituted for the sucrose ; this is now recommended in our treatment schedule (Staff, 1968). The occasional child is intolerant of all sugars, and for these the prognosis is grave. A few experiments with carbohydrate- 
free diets were made, attempting to introduce fructose gradually, but with little success.

Dr. H. C. Knight and Sisters A. Court, E. Strange, C. Roberts, G. Crew, and M. Hood helped in the care of the children, and Miss S. Ward and Mr. J. B. Kiwanuka gave technical help. We are grateful to all of them, and to Professor R. A. McCance for his help in the preparation of this report.

Requests for reprints should be addressed to: Medical Research Council Infantile Malnutrition Research Unit, P.O. Box 7051, Kampala, Uganda.

\section{REFERENCES}

Anderson, C. M., Kerry, K. R., and Townley, R. R. W. (1965). Arch. Dis. Childh., 40, 1. Arthur, A. B., Clayton, B. E., Cottom, D. G., Seakins, J. W. T., and
Platt, J. W. (1966). Lancet, 1, 172.
Barker, S. B., and Summerson, W. H. (1941). F. biol. Chem., 138, 535. Bowie, M. D., Barbezat, G. O., and Hansen, J. D. L. (1967). Amer. f. clin. Nutr., 20, 89.

Bowie, M. D., Brinkman, G. L., and Hansen, J. D. L. (1965). F. Pediat., 66, 1083.

Cook, G. C., and Kajubi, S. K. (1966). Lancet, 1, 725.

Correa (1908). Rev. méd. Yucatan, 3, No. 6.

Dean, R. F. A. (1952). E. Afr. med. f., 29, 1 .

Galván, R. R., and Calderon, J. M. (1965). Amer. F. clin. Nutr., 16, 351.

James, W. P. T. (1968). Lancet, 1, 333.

Kahn, E. (1959). S. Afr. med. F., 33, 501.

Scragg, J., and Rubidge, C. (1960). Brit. med. f., 2, 1759.

Staff, T. H. E. (1968). East Afr. med. $¥$. In press.

Stanfield, J. P., Hutt, M. S. R., and Tunnicliffe, R. (1965). Lancet, 2, 519.

Viteri, F. E., Flores, J. M., and Behar, M. (1967). VII International Conference of Nutrition, Hamburg, vol. 4, p. 46, edited by J. Kühnan and H. D. Crerner, Oxford.

Wharton, B. A. (1968). In Protein Deficiencies and Calorie Deficiencies, edited by R. A. McCance and E. Widdowson. London. In press.

\title{
Sugar Intolerance in Malnourished Infants and Children
}

\author{
R. K. CHANDRA, ${ }^{*} \dagger$ M.D., F.C.C.P. ; R. R. PAWA,* M.B., B.S. ; O. P. GHAI,* M.D., D.C.H.
}

Brit. med.F., 1968, 4, 611-613

\begin{abstract}
Summary : Of 100 malnourished Indian infants and children 50 showed a stool pH below 6. Carbohydrate-loading tests demonstrated intolerance to lactose in 39 , to sucrose in 25 , and to maltose in 15 . D-Xylose absorption was reduced in 16. Steatorrhoea was detected in 7 of 18 children tested. Nutritional recovery reversed the abnormalities in all except four, in whom a primary enzymic deficiency was considered on the basis of persistent lactose intolerance and a positive family history.
\end{abstract}

\section{Introduction}

Diarrhoea is an almost inseparable component of the clinical picture of malnutrition, particularly kwashiorkor. With mounting evidence that infections and infestations do not have a primary role in its aetiology, diarrhoea was attributed to the various pathological changes of nutritional deficiency-fatty liver, atrophic pancreas, and thin-walled small intestine (Trowell et al., 1954). Dean (1957) originally suggested that the lactose of milk was the cause of severe diarrhoea encountered in cases of advanced kwashiorkor. Since then there have been sporadic reports of dissacharide intolerance in malnourished children (Cevini et al., 1962 ; Careddu et al., 1963 ; Bardare et al., 1965 ; Kerpel-Fronius et al., 1966. The largest series by Bowie et al. (1965) concerned 16 patients with acquired fermentative diarrhoea; oral carbohydrate-loading tests were done in only five cases. We present tolerance studies on 100 malnourished infants and children.

\section{Patients and Methods}

A group of 100 children, aged 3 months to 5 years, were diagnosed as suffering from protein-calorie malnutrition on the basis of their weight being below the 10th percentile of local standards for normal children, as shown in Fig. 1 (Ghai and Sandhu, 1968). Other physical signs such as loss of subcutaneous fat, light and sparse hair, sunken eyeballs, anaemia, and avitaminosis $\mathrm{A}$ and $\mathrm{B}$, were seen in varying degrees and

\footnotetext{
* Department of Paediatrics, All-India Institute of Medical Sciences, New Delhi 16.

† Present address, and for requests for reprints: Department of Immunology, Institute of Child Health, 30 Guilford Street, London W.C.1.
}

combinations. Oedema, hepatomegaly, and pigmentary skin changes were observed in seven children. The $p \mathrm{H}$ of the stools was determined by a narrow-range $p H$ paper. Patients with a faecal $p \mathrm{H}$ below 6 on three samples were studied further, as under.

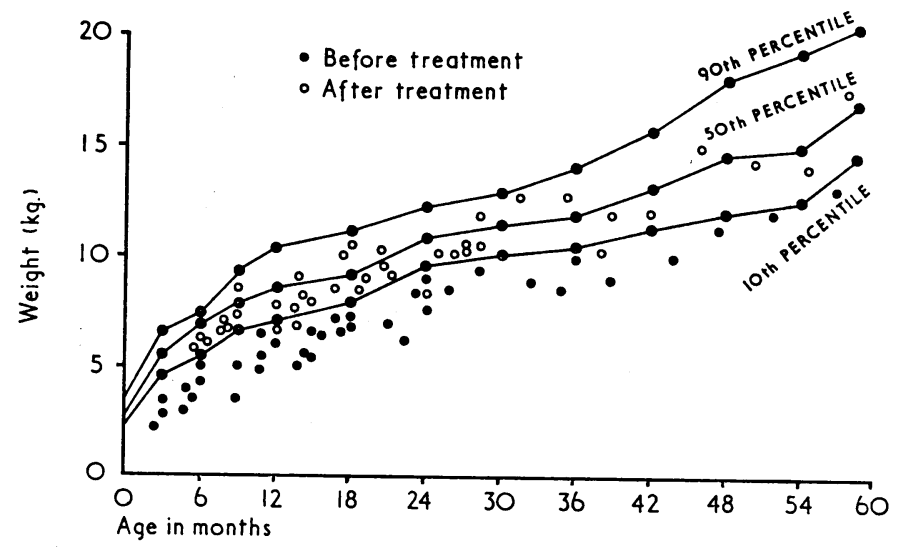

FIg. 1.-Weight distribution of patients initially and after nutritional recovery, plotted against curves for normal children (Ghai and Sandhu,

Carbohydrate tolerance tests were performed using lactose, sucrose, and maltose. Diarrhoea, if present, was controlled by using a diet low in disaccharides for a few days. After a fourhour fast the test substance was given orally in the dose of $2 \mathrm{~g} . / \mathrm{kg}$. body weight, as a $10 \%$ aqueous solution. Blood sugar was estimated by the Nelson-Somogyi method at 0, 30, 60, 90, and 120 minutes. Clinical symptoms developing during the test or within a few hours of it were noted. The absorption curve was thought to be flat if the maximal rise in blood sugar over fasting level was less than $30 \mathrm{mg} . / 100 \mathrm{ml}$. In that event the tolerance test was repeated, using the component monosaccharide/s as the loading substance-glucose and galactose in the case of lactose, glucose and fructose for sucrose, and glucose alone for maltose.

After an oral dose of $5 \mathrm{~g}$. of D-xylose its excretion in the urine was measured over a five-hour period by the method of Roe and Rice (1948). Values below $1 \mathrm{~g}$. were regarded as abnormal. Faecal fat was estimated by the method of van de 